\title{
Island pedicle advancement flap: An effective technique for the repair of nasolabial defects
}

\author{
Nazolabial bölge tamirinde etkili bir yöntem-pediküllü ilerletme ada flebi
}

\section{Leyla Huseynova, ๑ Gonca Elçin}

Hacettepe University Faculty of Medicine, Department of Dermatology, Ankara, Turkey

\section{What is an island pedicle advancement flap?}

An island pedicle flap, also known as a V-Y advancement flap, is a modified type of advancement flap. It is a highly useful reconstructive option for small-to intermediate-sized defects. Because of the lack of cutaneous connection, an island pedicle flap is more mobile than other advancement and rotation flaps ${ }^{1}$.

\section{Where can I use the island pedicle advancement flap?}

With significant subcutaneous fat, the amount of movement one might achieve with the island pedicle advancement flap depends primarily on the thickness of subcutaneous fat tissue; the thicker the tissue under the flap, the more mobility can be achieved ${ }^{2}$. Thus, the island pedicle advancement flap can be used for defects almost anywhere on the face, including the glabella, cheek, nose, and lip cosmetic units ${ }^{2}$. It is especially useful for repairing defects of the alar sill, alar facial junction, nasolabial area, and philtrum of the upper lip3,4. It is not recommended for defects located on the scalp, where desirable tissue mobility cannot be obtained by undermining, and incisions extending to the galea significantly decrease the blood supply of the flap ${ }^{2}$.

\section{How to design an island pedicle advancement flap?}

The design of the island pedicle advancement flap consists of a triangle with its base-(short side) standing on the surgical defect; the apex angle of this triangle is $30^{\circ}$. Two-longer sides of the triangle should be placed along the resting skin tension lines (RSTLS). Depending on the defect and the direction of the RSTLS, the longer sides of the triangle may be either linear or slightly curved in shape. Incisions should follow the natural curves of the face to camouflage the final appearance of the surgical scar ${ }^{5}$.

\section{Importance of proper execution and undermining of} the island pedicle flap

After the appropriate triangle is drawn, an incision must be made that penetrates the entire thickness of the subcutaneous fat. Then, the flap can be mobilized and advanced into the surgical defect. Narrowing the pedicle is crucial to achieve the desired tissue movement, but excessive narrowing may severely compromise perfusion to the flap ${ }^{2}$. As an island pedicle flap is created in a random-based perfusion pattern, the cross-sectional area of the pedicle should be roughly equal to the overlying skin to preserve the perfusion to the greatest extent. It is suggested to angle scissors downwards during the dissection to minimize transecting the pedicle base ${ }^{3}$.

\section{What are the advantages of the island advancement flap?}

The island pedicle advancement flap has several advantages over other advancement flaps. The first and most important

Address for Correspondence:Yazışma Adresi: Leyla Huseynova MD, Hacettepe University Faculty of Medicine, Department of Dermatology, Ankara, Turkey Phone: +90 5078086764 E-mail: leyla.huseynova@ymail.com Received/Geliş Tarihi: 02.02.2021 Accepted/Kabul Tarihi: 04.03.2021 ORCID: orcid.org/0000-0003-3562-1491

Cite this article as: Huseynova L, Elçin G. Island pedicle advancement flap: An effective technique for the repair of nasolabial defects. Turkderm-Turk Arch Dermatol Venereol 2021;55:153-5.

CCopyright 2021 by Turkish Society of Dermatology and Venereology

Turkderm - Turkish Archives of Dermatology and Venereology published by Galenos Yayınevi. 
characteristic of this flap is that it enables a greater degree of tissue mobility to be achieved than with other advancement flaps. Depending on the individual's anatomy, the island pedicle flap can be advanced up to $3-4 \mathrm{~cm}$ in the nasolabial fold ${ }^{2}$. The other advantage of an island pedicle flap is its ability to close the secondary defect without excising the Burow's triangle ${ }^{2}$. The proper-sized pedicle consists of subcutaneous tissue with abundant blood vessels that provide an excellent blood supply from the underlying tissue. Thus, an island pedicle flap can be designed much larger than a single advancement flap since it is without the concern of consequent hypoperfusion. In contrast, a single advancement flap gets its perfusion from its distally attached part². Another benefit of the island pedicle flap is the use of tissue directly adjacent to the surgical defect with a maximum matching of the skin in color, texture, thickness, and degree of actinic skin damage ${ }^{3}$.

\section{Case Report}

Herein, we present a 65-year-old woman admitted to our clinic with a residual basal cell carcinoma (BCC) in the previous excision area, as revealed in her pathology report. The patient underwent elliptical excision in another clinic with primary closure for BCC located on the right nasolabial area 4 months ago. Her pathologic examination was consistent with BCC of the micronodular type. Tumor was positive in the deep and lateral surgical margins. Dermatologic examination revealed an $18 \times 2 \mathrm{~mm}$ linear scar of the previous excision on the right nasolabial area (Figure 1). The location on the face, aggressive histologic subtype, and positive surgical margins on the recent excision were the tumor characteristics that were indications for Mohs micrographic surgery ${ }^{6}$. The scar area was re-excised with Mohs surgery using 2-3 mm margins on each side of the scar. After the first stage of Mohs micrographic surgery, the lateral and deep surgical margins of the tumor were positive (Figure 2a). After the second stage of Mohs surgery, clear surgical margins were achieved with a resultant surgical defect of 30x15 mm (Figure 2b). This defect was repaired with the island advancement flap (Figure 3-5).

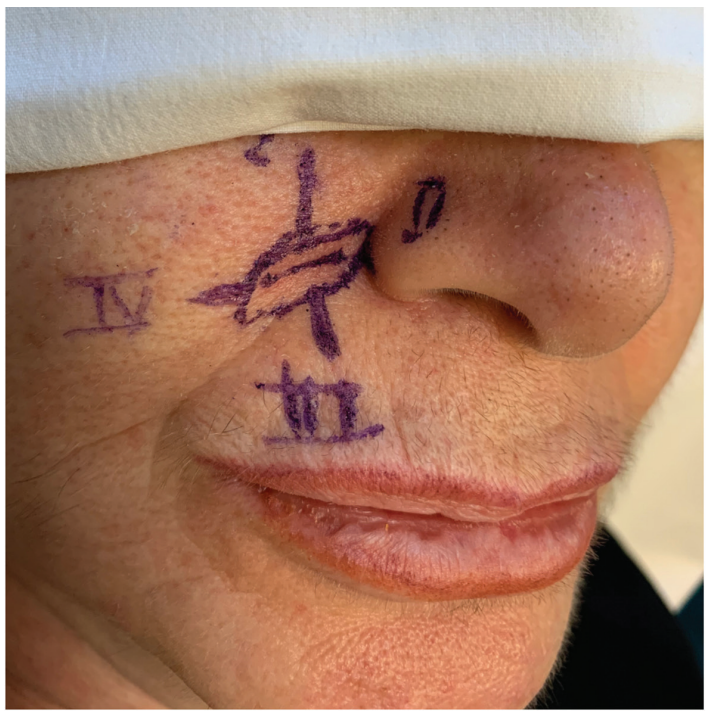

Figure 1. Linear scar of the previous excision with a size of $18 \times 2 \mathrm{~mm}$. The scar and the 2-3 mm margins for the first stage of Mohs surgery are marked with a surgical marker
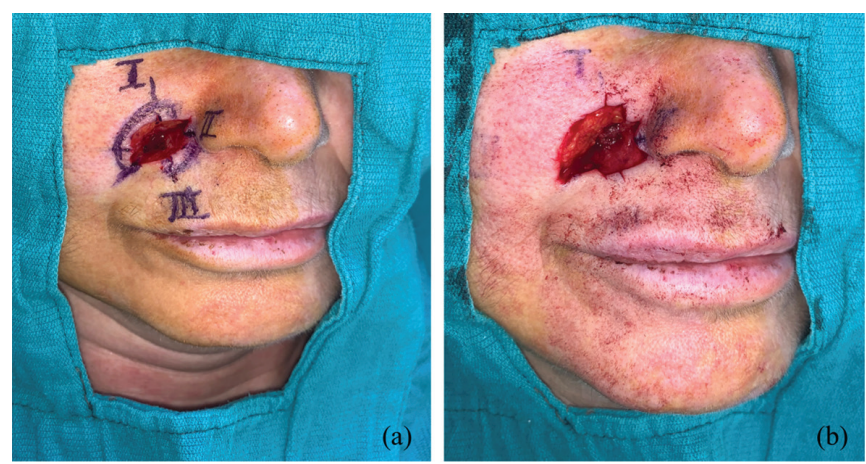

Figure 2. After the first stage of Mohs micrographic surgery, the lateral and deep surgical margins of the tumor were positive. The second stage of Mohs surgery was applied according to the information achieved from the Mohs cryosections (a). At the end of the second stage of Mohs surgery, clear surgical margins were achieved (b)

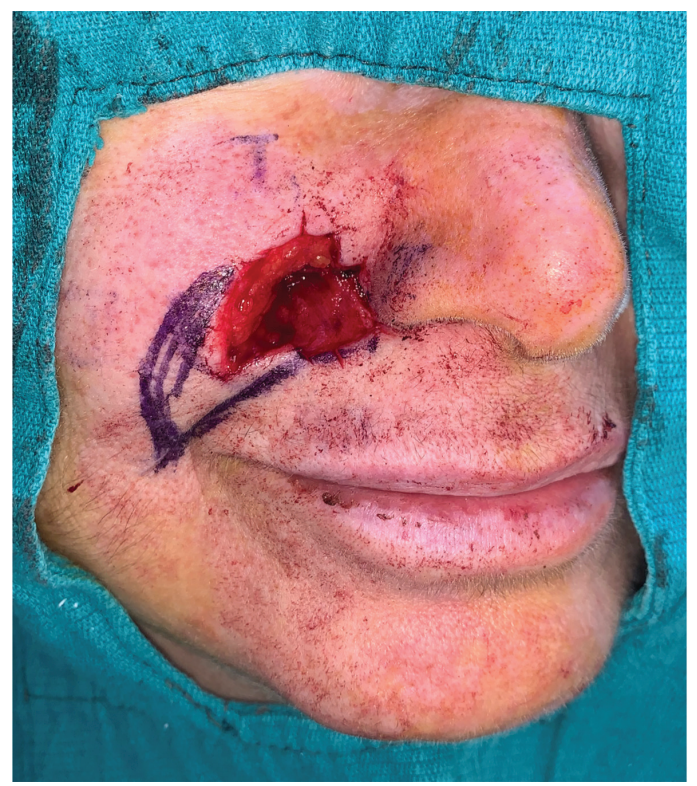

Figure 3. The resultant defect with a size of $30 \times 15 \mathrm{~mm}$. The design of the island pedicle advancement flap is described. Note that the sides of the flap are curvilinear as the incisions should follow the natural curves of the face and RSTLs to optimize cosmetic outcomes. The apex of the "triangle of the flap" is $30^{\circ}$
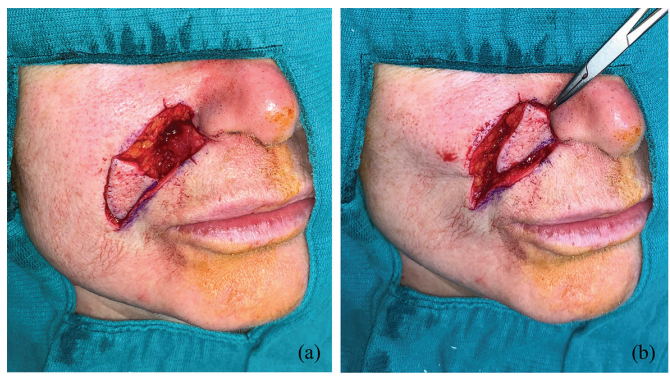

Figure 4. The thick subcutaneous tissue of the nasolabial area allows intended undermining without compromising perfusion, thus allowing advancement of the flap over large distances. As seen from the picture, the flap should be advanced at least $3-4 \mathrm{~cm}$ to reach the defect (a). The flap is size-matched to the defect and can be placed on the defect without tethering (b) 

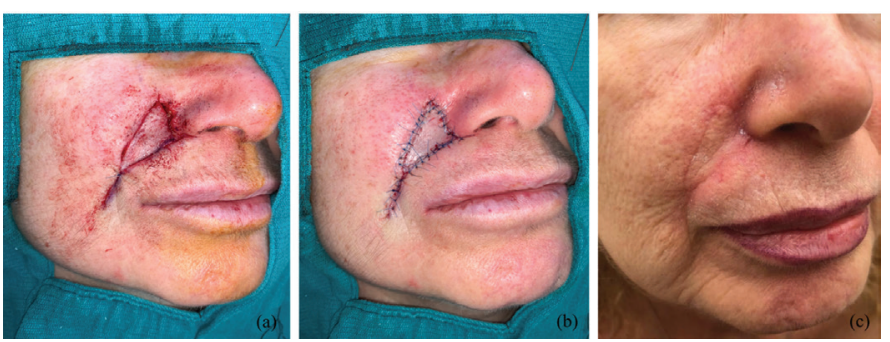

Figure 5. The flap is pegged into the defect with several subcutaneous sutures, which are very important to prevent bleeding to the flap area and avoid further mobility of the flap (a). The appearance of the flap right after the surgery (b). The final appearance of the flap area after suture removal (c)

Informed consent and permission for the publication of the patient's photos and medical data were obtained from the patient.

\section{References}

1. Brodland DG: Flaps. In: Bolognia JL, Schaffer JV, Cerroni L (editors). 4th edition. Dermatology, Elsevier; 2017;2495-616.

2. Krishnan R, Garman M, Nunez-Gussman J, Orengo I: Advancement flaps: A basic theme with many variations. Dermatol Surg 2015;31:986-94.

3. Kaufman AJ: Surgical gem: Island advancement flaps for lip reconstruction. Australas J Dermatol 2014;55:201-3.

4. Kojima $T$, Kinoshita $Y$, Hirase $Y$, Endo $T$, Hayashi H: Extended palmar advancement flap V-Y closure for finger injuries. Br J Plast Surg 1994;47:2759.

5. Braun M Jr, Cook J: The island pedicle flap. Dermatol Surg 2005;31:9951005.

6. Lam C, Vidimos AT: Mohs Micrographic Surgery. In: Bolognia JL, Schaffer JV, Cerroni L (editors). 4th edition. Dermatology, Elsevier; 2017;2542-54. 